\title{
Study on Longitudinal Ship Strength Caused by the Placement of Beams and Girders on Upper Deck Side
}

\author{
Andi Ardianti ${ }^{\mathrm{a}, *}$, Andi Mursid Nugraha ${ }^{\mathrm{b}}$, Ganding Sitepu ${ }^{\mathrm{c}}$, Hamzah ${ }^{\mathrm{d}}$, Ade Khantari ${ }^{\mathrm{e}}$, Suandar Baso ${ }^{\mathrm{f}}$ \\ ${ }^{a}$ Departement of Naval Architecture, Engineering Faculty, Hasanuddin University. Email: aardianti@gmail.com \\ bepartement of Naval Architecture, Engineering Faculty, Hasanuddin University. Email: andi.mursid08@gmail.com \\ 'Departement of Naval Architecture, Engineering Faculty, Hasanuddin University. Email: g.sitepu@unhas.ac.id

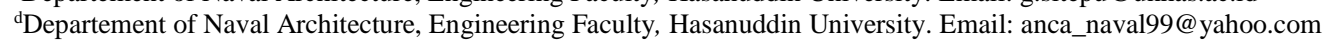 \\ eDepartement of Naval Architecture, Engineering Faculty, Hasanuddin University. Email: ade.khantari@gmail.com \\ fDepartement of Naval Architecture, Engineering Faculty, Hasanuddin University. Email: andar_baso@yahoo.co.id
}

\begin{abstract}
The location of the beam and the deck girder of the ship can be effect on it is strength especially for the longitudinal strength due to the vertical wave bending moment. The objective of this study is to know the structural response of the ship due to vertical bending moment load on hogging and sagging conditions. The analysis is carried out by using Finite Element Method so-called ANSYS ${ }^{\mathrm{TM}}$. The results shows that the stress occurring on the ship model with deck beam above the deck plate is larger than the ship model with deck beam under the deck plate. When the load with the variated of $0.2 \mathrm{x}$ moment of vertical moment load, there is an increase of stress that occurs both on the deck area about $12 \%$ while on the bottom area about $0.98 \%$. This study also conducted a stress comparison by using analysis methods with analytical methods. The results show that by the Stress differences that occur in the structure with the longitudinal deck beam and deck girder above are $14.1 \%$ on the deck and 7.1 on the bottom. Whereas in the structure with deck longitudinal deck eam and deck girder under there is a difference of $5.7 \%$ on the deck area and $3.5 \%$ in the bottom area of the ship. The stress that occur in both models have a difference that is not too far away and still under the permisible stress by the classification society so that both can be applied to the construction of a tanker.
\end{abstract}

Keywords: Deck beam; deck girder; longitudinal strength; stress; tanker

\section{Introduction}

Technical feasibility is one of important aspect in order to build a ship. Technical aspects that must be considered are the strength of ship construction. Ship construction will be good if it is able to withstand the load acting on it. The load type that works on the ships structure consist of internal load and external load. Internal loads are caused by loading on the ship and external loads caused by ocean waves and the position of the ship against the waves themselves and also the wind. While the benchmark that can guarantee the strength of the ship's structure is the stress (stress) experienced by the construction on the ships structure.

To ensure the feasibility of ships structure, regulations on ship construction planning have been issued by the classification bureau in various countries. Ships designed according to class regulations are expected to be able to

\footnotetext{
${ }^{*}$ Corresponding author. Tel.: +62 8128785620

Jl. Malino, Borongloe, Bontomarannu, Kabupaten Gowa, Sulawesi Selatan 921119
}

withstand the load that works while the ship is operating. The thing that needs to be considered in the planning is the continuous distribution of stress flow. The position of ship construction must be avoided by misalignment so that the load distribution is maintained

The ships structure is also efficiently designed to maximize the loading function of the ship. One method of efficiently ship is the installation of deck beams and girders above deck plates on tankers. By using this method, cargo tank will be completely clean on all sides.

The deck beams and deck girder that installed above deck plates may affect the behavior of deck structures in hogging and sagging conditions. Thus, it is important to analyze the impact of deck beams and deck girders placement above deck plates behavior and also the vertical bending moments. For this reason, this study conducted to analize the structure stress due by differences the deck beam and deck girders locations on tankers where the first condition is the deck beam and deck girders installed above the deck plate (Model 1). The second condition is deck beam and deck girders installed under the deck plate (Model 2). 


\section{Literature Review}

\subsection{Tanker}

Tanker is a type of ship that carry large amounts of flammable oil. As a result, it should build differently from other ships [1]. The requirements that shoud be considered to design a tanker are:

- The stability of tanker is strongly influenced by the effect of free surface of the fluid in the tank

- The cleaning of the oil that settles around the tank makes a lot of pressure on the structural elements of the tanker.

- The surface change of the liquid that is loaded due to temperature expansion and cargo contraction that requires the installation of an expansion trunk in the cargo tank.

- The process of loading and unloading is faster so that it uses less time at the port (not more than one day at a time).

- Tankers implement a one-way traffic system where the vessel is always empty on one route so that it requires sufficient ballast systems.

- Fire risk must be considered and a special ventilation system is applied to allow to release gas, all of task must be resistant to oil.

- Oil can have a very corrosive effect on the hull constructions

\subsection{Tanker construction}

According to the Lloyd's Register (LR), generally a ship requires full longitudinal framing if the length of the ship exceeds $150 \mathrm{~m}$ [2]. Tankers with longitudinal construction have longitudinal bottom frames and longitudinal decks through the tank room. In some cases of tankers, decks beam was installed on top of the deck plates to maximize the ship's loading function and so that the loading tank was completely clean on all sides.

\subsection{Loads on the ships hull}

According to Rasyid [3], loads that work on ship structures can be grouped into four types, namely:

- Static load,

- Low frequency dynamic loads

- High frequency dynamic loads

- Collition loads

According to Shama [4], the load of hull girder can be categorized as follows:

1. Bending moment

2. Shear load

3. Torsional load

4. Local load

Still water bending moments accounts for an important part of the shear force and bending moment on most ships, wave-induced effects must be added.

The main components of the bending moment of the ships beam are:

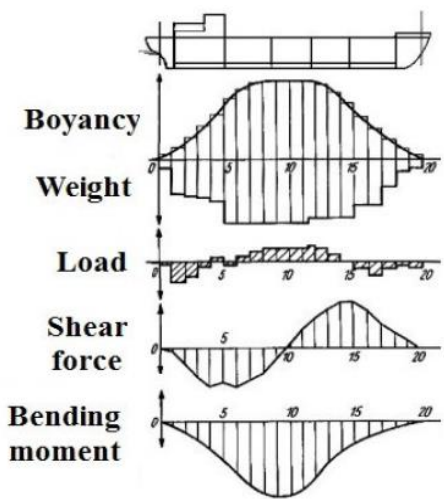

(a)

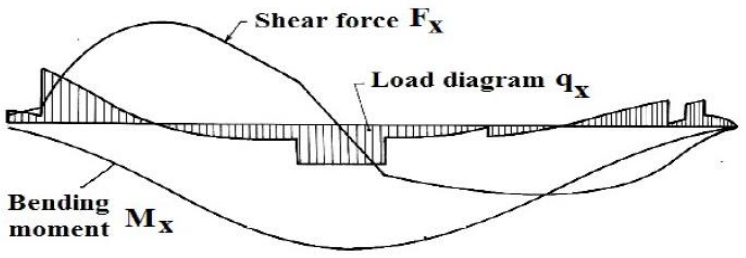

(b)

Figure 1. (a) Load Distributions, Shear Force, and Bending Moments. (b) Combined of Load Distribution, Shear Force, and Bending Moments [4]

a. Still water bending moments

b. Wave bending moments

c. Dynamic bending moments (whipping, slamming, springing)

The bending moment is caused by the load acting on the center of a structure, it is causing the structure to curve.

- Still water bending moments

The bending moment load in still water and the shear force is obtained from the buoyancy distribution (water pressure point) and the weight along the lengthwise construction of the ship as shown in Fig. 1a. Figure 1b shows the combination graph of load distribution, shear force, and bending moment.

- Wave bending moment

This moment is caused by wave conditions such as hogging and sagging conditions. In hogging conditions, the ship get a tensile strenght on the bottom and pressure on the deck. In contrast to sagging conditions. For more details, see Fig. 2.

According to BKI Vol. II [5], the moment caused by wave may be determined by using Eq. 1 below:

$$
\mathrm{M}_{\mathrm{WV}}=\mathrm{L}_{2} \cdot \mathrm{B} \cdot \mathrm{c}_{0} \cdot \mathrm{c}_{1} \cdot \mathrm{c}_{\mathrm{L}} \cdot \mathrm{c}_{\mathrm{m}}(\mathrm{KN} . \mathrm{m})
$$

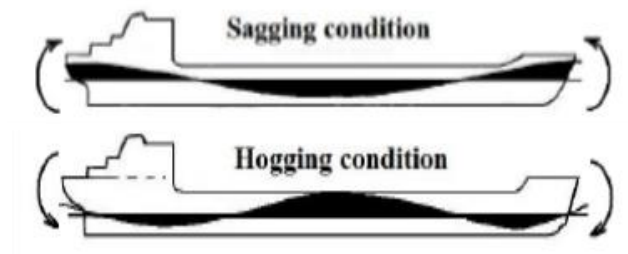

Figure 2. Sagging and Hogging Conditions [4] 
where,
$L \quad$ : Ships length
(m)

$\mathrm{C}_{0}$ : Wave Coefficient, as follow;

$$
\begin{array}{ll}
=\left[\frac{L}{25}+4\right] C_{R W} & \text { for } \mathrm{L}<90 \mathrm{~m} \\
=\left[10,75-\left(\frac{300-L}{100}\right)^{1,5}\right] C_{R W} & \text { for } 90 \mathrm{~m} \leq \mathrm{L} \geq 300 \mathrm{~m} \\
=10,75 \cdot C_{R W} & \text { for } \mathrm{L}>300 \mathrm{~m}
\end{array}
$$

$\mathrm{C}_{\mathrm{RW}}$ : service range coefficient

$$
\begin{aligned}
& =1,00 \text { for unlimited service range } \\
& =0,90 \quad \text { for service range } \mathrm{P} \\
& =0,75 \text { for service range } \mathrm{L} \\
& =0,60 \quad \text { for service range } \mathrm{T}
\end{aligned}
$$

$\mathrm{C}_{1}$ : sagging/hogging condition as follow

$$
\begin{array}{ll}
\mathrm{C}_{1 \mathrm{~h}}=0,19 . \mathrm{Cb} & \text { for hogging condition } \\
\mathrm{C}_{1 \mathrm{~s}}=-0.11(\mathrm{Cb}+0,7) & \text { for sagging condition }
\end{array}
$$

$\mathrm{C}_{\mathrm{L}}=\sqrt{\frac{L}{90}}$

for $\mathrm{L}<90 \mathrm{~m}$

$$
=1,0
$$

for $\mathrm{L}>90 \mathrm{~m}$

$\mathrm{Cm} \quad$ : distribution factor, see Fig. 3

$\mathrm{C}_{\mathrm{MH}}$ : hogging condition

$$
\begin{array}{ll}
=2.5 \cdot \frac{X}{L} & \text { for } \frac{X}{L}<0.4 \\
=1.0 & \text { for } 0.4 \leq \frac{X}{L} \leq 0.65
\end{array}
$$

$=\frac{1-\frac{X}{L}}{0.35}$

for $\frac{X}{L}<0.65$

$\mathrm{C}_{\mathrm{MS}}$ : sagging conditon

$$
\begin{aligned}
& =C v 2.5 \cdot \frac{X}{L} \\
& \text { for } \frac{X}{L}<0.4 \\
& =C v \\
& \text { for } 0.4 \leq \frac{X}{L} \leq 0.65 \cdot C v
\end{aligned}
$$

$=C v \cdot \frac{\frac{X}{L}-0.65 \cdot C v}{1-C v} \quad$ for $\frac{X}{L}<0.65 \cdot C v$

$\mathrm{C}_{\mathrm{v}} \quad$ : influence with regard to speed $\mathrm{v}_{0}$ of the vessel

$$
\begin{array}{ll}
=\sqrt[3]{\frac{v_{0}}{1.4 \cdot \sqrt{L}} \geq 1.0} & \text { for } 1.4 \cdot \sqrt{L} \geq 14 \\
=1.0 & \text { for damaged cond }
\end{array}
$$

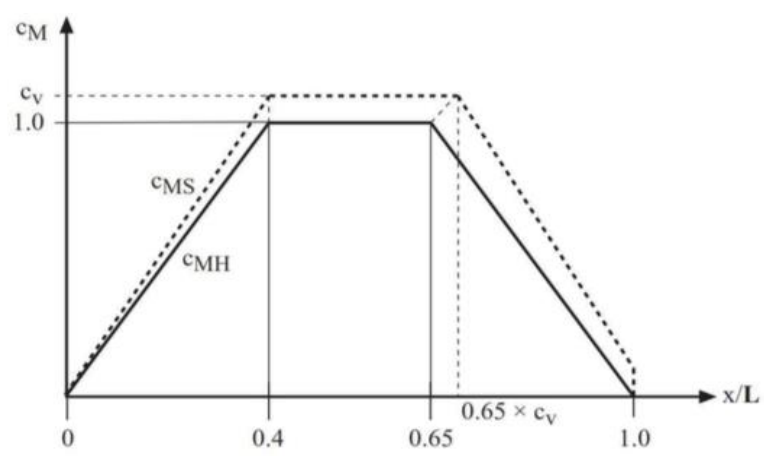

Figure 3. Distribution factor $\mathrm{c}_{\mathrm{M}}$ and influrnce factor $\mathrm{C}_{\mathrm{v}}[5]$

\subsection{Stress and strain}

Stress is defined as the amount of force acting per unit area. There are two types of stress: normal stress and shear stress. Normal stress $(\sigma)$ is normal force or axial force per unit area [6]. Mathematically, it is formulated as follows:

$$
\sigma=\frac{F}{A}
$$

where:

$$
\begin{array}{ll}
\sigma & =\operatorname{stress}\left(\mathrm{N} / \mathrm{mm}^{2}\right) \\
F & =\text { force or } \operatorname{load}(\mathrm{N}) \\
A & =\text { face area }\left(\mathrm{mm}^{2}\right)
\end{array}
$$

Strain is expressed as the increase of length per unit length. Hooke's law states that within certain limits, the stress on a material is directly proportional to the strain. Strain can be written as:

$$
\varepsilon=\frac{\Delta L}{L}
$$

where:

$$
\begin{array}{ll}
\varepsilon & =\text { strain }\left(\mathrm{N} / \mathrm{mm}^{2}\right) \\
\Delta L & =\text { total of length increase }(\mathrm{mm}) \\
L & =\text { initial lenght }(\mathrm{mm})
\end{array}
$$

Stress is static amounts, it is a measure for pressure on structural materials. On the other hand, strains are kinematic amounts; it measures structural deformation. However, deformation depends on the load acting on the structure. Therefore, the stress and strain are not independent. The physical relationship that links this number is called constitutive law. This describes the behavior of structures material under load. It depends on the material and can only be obtained with the help of experiments [7].

One of the most important experiments to find the relationship between stress and strain is the tension or compression test. Here, small specimens of material are placed into the test machine and are elongated or shortened. The force $\mathrm{F}$ applied by the machine to the specimen can be read at the engine speed; That causes normal stress $\sigma=F$ / $A$. The change of $\Delta l$ from the length of the specimen can be obtained and strain can be measured by using $\varepsilon=\Delta l / l$.

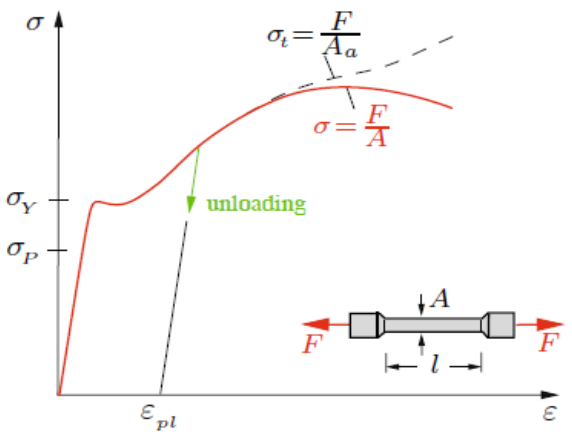

Figure 4. Stress - Strain Curve [7] 
The graph of the relationship between stress and strain is shown schematically (not scaled) for the steel specimen in Fig. 4. This graph is called a stress-strain diagram. The graph show that for small values of strain, the relationship is linear (straight line) and the stress is proportional to the strain. This behavior applies until the stress reaches the proportional limit $\sigma P$. If the stress exceeds the proportional limit, the strain begins to increase faster and the slope of the curve decreases. This continues until the stress reaches the yield stress $\sigma Y$. From this point, the stress-strain diagram show that strain increases at constant stress. Note that many materials do not show clear results points. At the end of the slope the curve increases again which indicates that the material can maintain additional load. This phenomenon is called strain hardening.

\subsection{Permissible stress}

Permit stress is the stress that causes a construction to experience a large deflection, where the deflection is the limit of a construction that still safe to overcoming the load that occurring or working on it. If the permit stress of the construction concerned is smaller than the maximum stress that occurs, then the construction is not safe.

Based on BKI rules, the normal strength of the steel hull structure is that the hull steel structure has a yield point of $\mathrm{REH}=235 \mathrm{~N} / \mathrm{m}^{2}$ and tensile strength $\mathrm{Rm}=400-520 \mathrm{~N} / \mathrm{m}^{2}$.

The stress acting on the structure can be evaluated by using the value of the permit stress issued by the classification bureau which is $150 / \mathrm{k}\left[\mathrm{N} / \mathrm{mm}^{2}\right]$. If the working stress that occurs in the conditions of loading the vertical bending moment exceeds the permit stress, the structure or object of the research in an unsafe condition and if the working stress value is less than the value of the permit stress, the structure is in safe condition or meets the rules standards.

\subsection{Finite Element Method}

Finite Element Method is a numerical method used to solve technical and mathematical problems of a physical phenomenon. The types of physical and mathematical problems that can be solved by finite element methods are structural and non-structural analysis. The type of structural analysis problem includes stress analysis, buckling and vibration analysis. The type of non-structures analysis include heat and mass transfer, fluid mechanics, and the potential distribution of electricity and magneticity [8].

By using Finite Element method, all the complexity of the problem, such as various forms, boundary conditions and loads are maintained but the solutions obtained are estimates number. This is because of its diversity and flexibility as an analytical tool. Quick improvements in computer hardware technology and reduced computer costs have driven this method, because computers are a basic need for the application of this method. A number of popular brand element analysis packages are now commercially available to simplify a complex structure analysis [9]. Some popular packages are STAAD-PRO, GT-STRUDEL, NASTRAN, NISA and ANSYS.

\section{Research Methodology}

\subsection{Tankers data}

The models on this study is a tanker with longitudinal framing length less than $150 \mathrm{~m}$, and also the construction of deck beams is above the deck plate. For this reason, this research was conducted to determine the effect of laying the beam against the longitudinal strength of the ship. The data needed for this research is the main dimentions of the tanker, as follow:

$\begin{array}{lll}\text { Ships Type } & : 6500 \text { LT DWT OIL TANKER } \\ \text { LOA } & : 108 & \text { meter } \\ \text { B } & : 19.2 & \text { meter } \\ \text { H } & : 9.3 & \text { meter } \\ \text { T } & : 6 & \text { meter }\end{array}$

Type of plate material based on ABS [10] are:

\begin{tabular}{|c|c|c|}
\hline Grade & A & (ABS Rules) \\
\hline Tensile Strength & 550 & $\left(\mathrm{~N} / \mathrm{mm}^{2}\right)$ \\
\hline Yield Point & 235 & $\left(\mathrm{~N} / \mathrm{mm}^{2}\right)$ \\
\hline Temperature & 20 & $\left({ }^{\circ} \mathrm{C}\right)$ \\
\hline Young's modulus & 2,06 & $105\left(\mathrm{~N} / \mathrm{mm}^{2}\right)$ \\
\hline Poisson ratio & 0,3 & \\
\hline
\end{tabular}

\subsection{Structure modeling}

Modeling is done by using ANSYS ${ }^{\mathrm{TM}}$ software, the modeling started from defining the element type, installing constraints, loading and analyzing results. The steps in modeling the structure of the load space are:

- Structural modeling, tanker structure is modeled in two ways, installing the deck beams and deck girders above deck plates and installing the beams and deck supports under deck plates. The modeled part of the tanker's construction is frame 85 - 90 with distance $650 \mathrm{~mm}$.

- The element type that used is the shell element type 63 . The shell element type is selected because it is suitable for plate modeling and has six degrees of freedom for each node.

- Meshing, meshing size and quality is very important to obtain a good result, but the smaller the meshing value, the computer device used must have high specifications. In this study, the meshing size used was $100 \mathrm{~mm}$ in quad mapped form.

- Installation of constraints and the boundary conditions applied to the finite element model is dependent on the type of load increase process that used. The boundary conditions in this study are all end points of the aft part model are given a full constraint. There is no loading at the reference point aft. At the end of the model section fwd at the reference point of the neutral axis, given the bending moment then all points at the end of the fwd are rigid full link constraints to the neutral axis reference point. The taking of the boundary conditions in this calculation is the pinch pedestal on one side and the simple support on the other side.

- Loading, in this analysis use the vertical bending moment in hogging and sagging conditions with reference to BKI rules. 
- Settlement, in general, there are two types of solutions, namely static analysis and dynamic analysis. In this analysis static analysis was carried out. Completion is carried out on the model in the form of elements according to the loading and conditions of the boundary conditions given to the model. This process is called running. At this stage finite element software runs the analysis process of the model that has been harmonized in element form until given certain boundary and load conditions.

\subsection{Loading variations}

Loading variations conducted to get the tendency of the tanker's structural response to any changes in load. In this study, the maximum vertical bending moment load is $4.59 \mathrm{x}$ $1011 \mathrm{~N} / \mathrm{mm}^{2}$ in hogging conditions and $-4.43 \times 1011 \mathrm{~N} / \mathrm{mm}^{2}$ in sagging conditions, the reference load is assumed to be $100 \%$ load. The load will decrease every multiple of $0.2 \mathrm{x}$ Total vertical bending moment (Mt) in hogging and sagging conditions.

\section{Numerical Result}

After the analysis process, the stress values that occur in each model were obtained. Figure 5 shows the example of the results of deck construction analysis by using software ANSYS. The input data is listed in Table 1.

Table 1. Value of Vertical bending moment variation

\begin{tabular}{ccc}
\hline \multirow{2}{*}{$\begin{array}{c}\text { Load } \\
\text { Variation }\end{array}$} & \multicolumn{2}{c}{ Vertical Bending Moment } \\
\cline { 2 - 3 } & Hogging Condition & Sagging Condition \\
\hline 0 & 0 & 0 \\
\hline $0.2 \times \mathrm{Mt}$ & $9.18 \mathrm{E}+10$ & $-8.86 \mathrm{E}+10$ \\
\hline $0.4 \times \mathrm{Mt}$ & $1.84 \mathrm{E}+11$ & $-1.77 \mathrm{E}+11$ \\
\hline $0.6 \times \mathrm{Mt}$ & $2.75 \mathrm{E}+11$ & $-2.66 \mathrm{E}+11$ \\
\hline $0.8 \times \mathrm{Mt}$ & $3.67 \mathrm{E}+11$ & $-3.55 \mathrm{E}+11$ \\
\hline $\mathrm{Mt}$ & $4.59 \mathrm{E}+11$ & $-4.43 \mathrm{E}+11$ \\
\hline
\end{tabular}

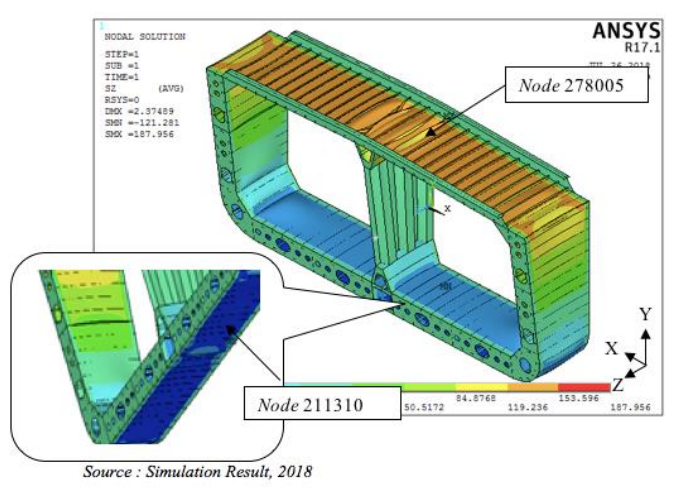

(a) Model 1

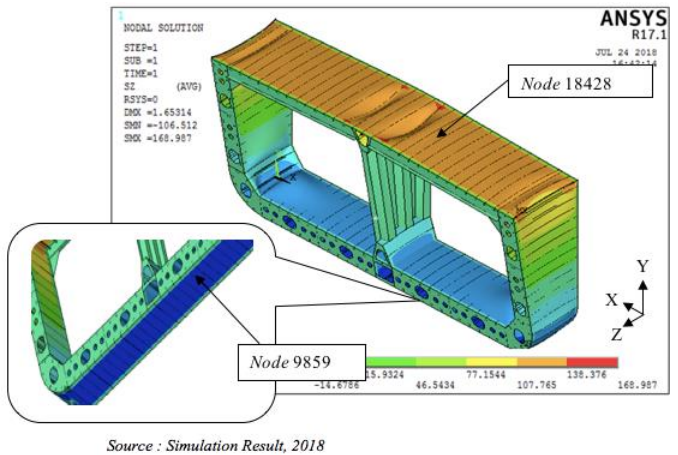

(b) Model 2

Figure 5. Behavior of stress distribution in hogging conditions with beams and deck supports above deck plate. (a) Model 1, tankers construction with deck beam and deck girder installed above the deck plate. (b) Model 2, tankers construction with deck beam and deck girder installed under the deck plate

From the results of the analysis, it will be reviewed about the maximum stress of the deck area and the bottom area of each model under hongging conditions and sagging conditions. Analysis is carried out at maximum stress because this voltage is considered to be the most influential in determining whether the structure meets the requirements or not.

Tabel 2. Stress that occurs during Hogging conditions

\begin{tabular}{cccccc}
\hline \multirow{2}{*}{$\begin{array}{c}\text { Load } \\
\text { Variation }\end{array}$} & $\begin{array}{c}\text { Moment } \\
\text { Hogging } \\
(\mathrm{Nmm})\end{array}$ & $\begin{array}{c}\text { Stresses } \\
\text { on deck } \\
\left(\mathrm{N} / \mathrm{mm}^{2}\right)\end{array}$ & $\begin{array}{c}\text { Stresses } \\
\text { on } \\
\text { Bottom } \\
\left(\mathrm{N} / \mathrm{mm}^{2}\right)\end{array}$ & $\begin{array}{c}\text { Stresses } \\
\text { on deck } \\
\left(\mathrm{N} / \mathrm{mm}^{2}\right)\end{array}$ & $\begin{array}{c}\text { Stresses } \\
\text { on } \\
\text { Bottom } \\
\left(\mathrm{N} / \mathrm{mm}^{2}\right)\end{array}$ \\
\hline 0 & $0,00 \mathrm{E}+00$ & 0 & 0 & 0 & 0 \\
\hline $0,2 \times \mathrm{Mt}$ & $9.18 \mathrm{E}+10$ & 27.576 & -16.466 & 24.035 & -16.301 \\
\hline $0,4 \times \mathrm{Mt}$ & $1.84 \mathrm{E}+11$ & 55.27 & -33.003 & 48.174 & -32.674 \\
\hline $0,6 \times \mathrm{Mt}$ & $2.75 \mathrm{E}+11$ & 82.608 & -49.325 & 72.00 & -48.833 \\
\hline $0,8 \times \mathrm{Mt}$ & $3.67 \mathrm{E}+11$ & 110.24 & -65.827 & 96.087 & -65.17 \\
\hline $\mathrm{Mt}$ & $4.59 \mathrm{E}+11$ & 137.88 & -82.328 & 120.17 & -81.507 \\
\hline
\end{tabular}

Table 3. Stress that occurs during Sagging Conditions

\begin{tabular}{cccccc}
\hline & & \multicolumn{2}{c}{ Model 1 } & \multicolumn{2}{c}{ Model 2 } \\
\cline { 3 - 6 } $\begin{array}{c}\text { Load } \\
\text { Variation }\end{array}$ & $\begin{array}{c}\text { Moment } \\
\text { Hogging } \\
\text { (Nmm) }\end{array}$ & $\begin{array}{c}\text { Stresses } \\
\text { on deck } \\
\left(\mathrm{N} / \mathrm{mm}^{2}\right)\end{array}$ & $\begin{array}{c}\text { Stresses } \\
\text { on } \\
\text { Bottom } \\
\left(\mathrm{N} / \mathrm{mm}^{2}\right)\end{array}$ & $\begin{array}{c}\text { Stresses } \\
\text { on deck } \\
\left(\mathrm{N} / \mathrm{mm}^{2}\right)\end{array}$ & $\begin{array}{c}\text { Stresses } \\
\text { on } \\
\text { Bottom } \\
\left(\mathrm{N} / \mathrm{mm}^{2}\right)\end{array}$ \\
\hline 0 & $0,00 \mathrm{E}+00$ & 0 & 0 & 0 & 0 \\
\hline $0,2 \times \mathrm{Mt}$ & -8.86 & -26.615 & 15.892 & -23.197 & 15.733 \\
\hline $0,4 \times \mathrm{Mt}$ & -1.77 & -53.17 & 31.748 & -46.342 & 31.431 \\
\hline $0,6 \times \mathrm{Mt}$ & $\begin{array}{c}\mathrm{E}+11 \\
\mathrm{E}+11\end{array}$ & -79.905 & 47.711 & -69.643 & 47.235 \\
\hline $0,8 \times \mathrm{Mt}$ & -3.55 & -106.64 & 63.674 & -92.945 & 63.039 \\
\hline $\mathrm{Et}$ & -4.43 & -133.07 & 79.458 & -115.99 & 78.666 \\
\hline
\end{tabular}




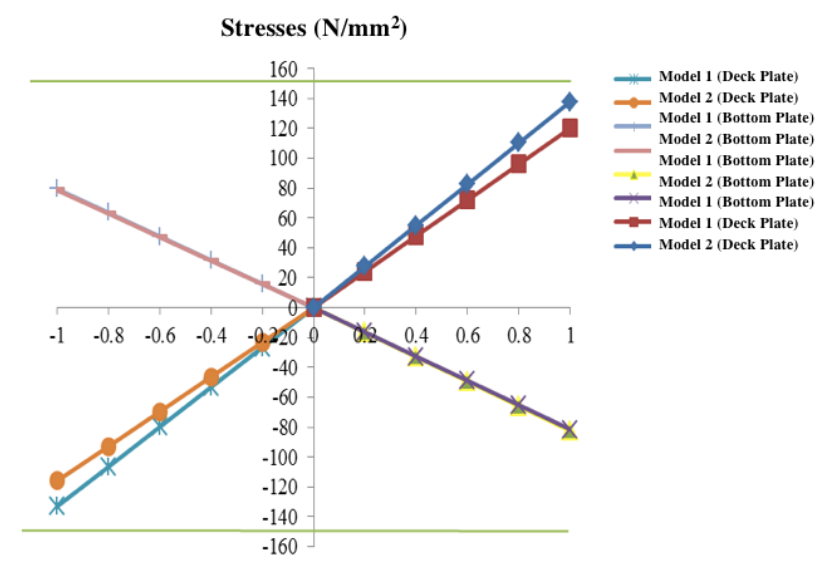

Figure 6. The relationship curve between the increase of the vertical bending moment and the working stress

According to Tables 2 and 3, it is known that the stress that occurs due to the vertical bending moment in the tankers constructin with deck beam and deck girder installed above the deck plate is greater than the stress that occurs in the tanker's construction with deck beam and deck girder installed under the deck plate both in hogging and sagging conditions. In hogging conditions, the difference stress that occurs on the deck area is $12.8 \%$ and the stress that occur on bottom area is $0.98 \%$. Whereas in sagging conditions, the stress difference that occurs in tankers construction with deck beam and deck girder intalled above deck plates comared with deck beam and deck girder installed under deck plates is $12.82 \%$ on deck area and $0.996 \%$ on bottom area. However, this stresses value are still below of the stress allowed by the BKI so the structure is concluded safe. Besides that, the stresses difference between the two structural models is not too much different.

The comparison of stresses that occur on the models with deck beam and deck girder construction lay on above deck plate and the models with beams and deck girder construction under the deck plate was show in Fig. 6.

Based on Table 4, the stress difference between FEA and Analytic on the deck area is $14.1 \%$ while on the bottom area is $7 \%$.

Table 4. Comparison of the stresses generated by using the FEA and analytic methods in Hogging condition for Model 1

\begin{tabular}{ccccccc}
\hline $\begin{array}{l}\text { Moment } \\
\text { Hogging } \\
(\mathbf{N m m})\end{array}$ & \multicolumn{3}{c}{ Deck Plate } & \multicolumn{3}{c}{ Bottom Plate } \\
\cline { 2 - 7 }$\left(\mathrm{N} / \mathrm{mm}^{2}\right)$ & $\begin{array}{c}\text { Analytic } \\
\left(\mathrm{N} / \mathrm{mm}^{2}\right)\end{array}$ & $\begin{array}{c}\text { Difference } \\
(\%)\end{array}$ & $\begin{array}{c}\text { FEA } \\
\left(\mathrm{N} / \mathrm{mm}^{2}\right)\end{array}$ & $\begin{array}{c}\text { Analytic } \\
\left(\mathrm{N} / \mathrm{mm}^{2}\right)\end{array}$ & $\begin{array}{c}\text { Difference } \\
(\%)\end{array}$ \\
\hline $0,00 \mathrm{E}+00$ & 0 & 0.00 & 0 & 0 & 0.00 & 0 \\
\hline $9.18 \mathrm{E}+10$ & 27.576 & 23.69 & 14.11 & -16.466 & -17.64 & 7.12 \\
\hline $1.84 \mathrm{E}+11$ & 55.27 & 47.37 & 14.29 & -33.003 & -35.28 & 6.89 \\
\hline $2.75 \mathrm{E}+11$ & 82.608 & 71.06 & 13.98 & -49.325 & -52.91 & 7.28 \\
\hline $3.67 \mathrm{E}+11$ & 110.24 & 94.74 & 14.06 & -65.827 & -70.55 & 7.18 \\
\hline $4.59 \mathrm{E}+11$ & 137.88 & 118.43 & 14.11 & -82.328 & -88.19 & 7.12 \\
\hline
\end{tabular}

Table 5. Comparison of the stresses generated by using the FEA and analytic methods in Sagging condition for Model 1

\begin{tabular}{ccccccc}
\hline $\begin{array}{c}\text { Moment } \\
\text { Hogging } \\
(\mathrm{Nmm})\end{array}$ & \multicolumn{3}{c}{ Deck Plate } & \multicolumn{3}{c}{ Bettom Plate } \\
\cline { 2 - 7 }$\left(\mathrm{N} / \mathrm{mm}^{2}\right)$ & $\begin{array}{c}\text { Analytic } \\
\left(\mathrm{N} / \mathrm{mm}^{2}\right)\end{array}$ & $\begin{array}{c}\text { Difference } \\
(\%)\end{array}$ & $\begin{array}{c}\text { FEA } \\
\left(\mathrm{N} / \mathrm{mm}^{2}\right)\end{array}$ & $\begin{array}{c}\text { Analytic } \\
\left(\mathrm{N} / \mathrm{mm}^{2}\right)\end{array}$ & $\begin{array}{c}\text { Difference } \\
(\%)\end{array}$ \\
\hline $0,00 \mathrm{E}+00$ & 0 & 0.00 & 0 & 0 & 0.00 & 0 \\
\hline $\begin{array}{c}-8.86 \\
\mathrm{E}+10\end{array}$ & -26.615 & -22.87 & 14.09 & 15.892 & 17.03 & 7.15 \\
\hline $\begin{array}{c}-1.77 \\
\mathrm{E}+11\end{array}$ & -53.17 & -45.73 & 13.99 & 31.748 & 34.06 & 7.27 \\
\hline-2.66 & -79.905 & -68.60 & 14.15 & 47.711 & 51.08 & 7.07 \\
\hline $\mathrm{E}+11$ & -106.55 & -91.46 & 14.23 & 63.674 & 68.11 & 6.97 \\
\hline $\mathrm{E}+11$ & -106.64 & -114.33 & 14.08 & 79.458 & 85.14 & 7.15 \\
\hline $\begin{array}{c}-4.43 \\
\mathrm{E}+11\end{array}$ & -133.07 & & & & & \\
\hline
\end{tabular}

Table 5 shows that the averaged stress difference on deck areas and bottom area analysis by using FEA and Analytical method about $14.1 \%$ on deck areas while in the bottom area was $7.1 \%$.

In addition to using ANSYS ${ }^{\mathrm{TM}}$ Software in this study, analytic calculations were performed to compare the results obtained in the FEA method. Comparison of stresses that occur between these two methods can be seen in Table 4 and Table 5. The result comparisons result for models with deck beam and deck girder construction installed above deck plate was show in Table 6 and the result for models with deck beam and deck girder installed under the deck plate was show in Table 7.

Table 7 shows that the stresses difference between FEA and Analytical on deck plate stress is $5.6 \%$ while on the bottom plate is $3.5 \%$. Table 6 shows that the stress difference between FEA and Analytic on deck plate is $5.7 \%$ while on the bottom plate is $3.55 \%$.

Table 6. Comparison of the stresses generated by using the FEA and analytic methods in Hogging condition for Model 2

\begin{tabular}{|c|c|c|c|c|c|c|}
\hline \multirow{2}{*}{$\begin{array}{c}\text { Moment } \\
\text { Hogging } \\
\text { (Nmm) }\end{array}$} & \multicolumn{3}{|c|}{ Deck Plate } & \multicolumn{3}{|c|}{ Bottom Plate } \\
\hline & $\begin{array}{c}\text { FEA } \\
\left(\mathrm{N} / \mathrm{mm}^{2}\right)\end{array}$ & $\begin{array}{l}\text { Analytic } \\
\left(\mathrm{N} / \mathrm{mm}^{2}\right)\end{array}$ & $\begin{array}{c}\text { Difference } \\
(\%)\end{array}$ & $\begin{array}{c}\text { FEA } \\
\left(\mathrm{N} / \mathrm{mm}^{2}\right)\end{array}$ & $\begin{array}{l}\text { Analytic } \\
\left(\mathrm{N} / \mathrm{mm}^{2}\right)\end{array}$ & $\begin{array}{c}\text { Difference } \\
(\%)\end{array}$ \\
\hline $0,00 \mathrm{E}+00$ & 0 & 0.00 & 0 & 0 & 0.00 & 3.56 \\
\hline $9.18 \mathrm{E}+10$ & 24.04 & 22.74 & 5.70 & -16.301 & -16.88 & 3.33 \\
\hline $1.84 \mathrm{E}+11$ & 48.17 & 45.48 & 5.93 & -31.674 & -33.76 & 3.71 \\
\hline $2.75 \mathrm{E}+11$ & 72.00 & 68.22 & 5.54 & -48.833 & -50.64 & 3.61 \\
\hline $3.67 \mathrm{E}+11$ & 96.09 & 90.96 & 5.64 & -65.17 & -67.53 & 3.56 \\
\hline $4.59 \mathrm{E}+11$ & 120.17 & 113.70 & 5.69 & -81.507 & -84.41 & 3.56 \\
\hline
\end{tabular}

Table 7. Comparison of the stresses generated by using the FEA and analytic methods in Sagging condition for Model 2.

\begin{tabular}{|c|c|c|c|c|c|c|}
\hline \multirow{2}{*}{$\begin{array}{c}\text { Moment } \\
\text { Hogging } \\
\text { (Nmm) }\end{array}$} & \multicolumn{3}{|c|}{ Deck Plate } & \multicolumn{3}{|c|}{ Bottom Plate } \\
\hline & $\begin{array}{c}\text { FEA } \\
\left(\mathrm{N} / \mathrm{mm}^{2}\right)\end{array}$ & $\begin{array}{l}\text { Analytic } \\
\left(\mathrm{N} / \mathrm{mm}^{2}\right)\end{array}$ & $\begin{array}{c}\text { Difference } \\
(\%)\end{array}$ & $\begin{array}{c}\text { FEA } \\
\left(\mathrm{N} / \mathrm{mm}^{2}\right)\end{array}$ & $\begin{array}{l}\text { Analytic } \\
\left(\mathrm{N} / \mathrm{mm}^{2}\right)\end{array}$ & $\begin{array}{c}\text { Difference } \\
(\%)\end{array}$ \\
\hline $0,00 \mathrm{E}+00$ & 0 & 0.00 & 0 & 0 & 0.00 & 3.56 \\
\hline $\begin{array}{l}-8.86 \\
E+10\end{array}$ & -23.197 & -21.95 & 5.67 & 15.733 & 16.30 & 3.58 \\
\hline $\begin{array}{l}-1.77 \\
E+11\end{array}$ & -46.342 & -43.90 & 5.55 & 31.431 & 32.59 & 3.70 \\
\hline $\begin{array}{l}-2.66 \\
\mathrm{E}+11\end{array}$ & -69.643 & -65.86 & 5.75 & 47.235 & 48.89 & 3.51 \\
\hline $\begin{array}{l}-3.55 \\
\mathrm{E}+11\end{array}$ & -92.945 & -87.81 & 5.85 & 63.039 & 65.19 & 3.41 \\
\hline $\begin{array}{l}-4.43 \\
\mathrm{E}+11\end{array}$ & -115.99 & -109.76 & 5.68 & 78.666 & 81.48 & 3.58 \\
\hline
\end{tabular}




\section{Conclusions}

This research conducted by using ANSYS 17.1 software and analysis by using Finite Element Method. Based on the result from this research can be concluded as below:

- The deck beam and deck girder position give effect to the magnitude of the cross-section modulus. By installing the deck beam and deck girder above the deck plate, it will increase the location of the center of gravity of the ship's structure by $2.3 \%$. Changes in the location of the center of gravity (Neutral Axis) will have an impact on the change in inertia moment of the cross section.

- The maximum stress that occurs in construction with deck beams and deck girder installing above deck plates is greater than the construction of ships with deck beams and deck girders under deck plates. In other words, the construction of a ship with deck reinforcement installing under the deck plate is better than the construction of a ship with a deck reinforcement that installing above the deck plate, although it is not significant.

- In both conditions, the stresses difference that occurs in both models construction are $12.84 \%$ on the deck plate and $0.98 \%$ on the bottom plate.
- Stress difference using Finite Element Analysys (FEA) method and analytical method in hogging conditions are $14.1 \%$ on deck plates and $7.1 \%$ on bottom plate. Whereas in sagging conditions the stress difference is $5.6 \%$ on the deck plate and $3.5 \%$ on the bottom plate

\section{References}

[1] Barabanov, N. 1972. Structural Design of Sea-Going Ships. Translated by: Oleg Sapunov. Peace Publisher. Moscow.

[2] Eyres, D.J. 2001. Ship Construction fifth edition. Butterworth Heinneman. London.

[3] Rasyid, Daniel Muhammad. 2000. Strength of Ship Structure. Pradnya Paramita. Jakarta. [in Bahasa Indonesia]

[4] Shama, Mohamed. 2013. Buckling of Ship Structures. Alexandria University, Egypt.

[5] Biro Klasifikasi Indonesia. 2014. Rules for the Clasification And Construction Seagoing Steel Ship, Volume II. BKI. Jakarta.

[6] Patnaik, Surya N. and Dale A. Hopkins. 2004. Strength of Materials. Elsevier. Amsterdam.

[7] Gross, Dietmar. 2011. Engineering Mechanics 2 "Mechanics of Materials". Springer. London.

[8] Susatio, Yerri. 2004. Basics of Finite Element Method. Andi. Yogyakarta. [in Bahasa Indonesia].

[9] Bhavikatti, S.S. 2005. Finite Element Analysis. New age International Publisher. New Delhi.

[10] ABS. 2013. Rules for Requirement Materials and Welding, USA. 